\title{
PENGARUH USIA DAN JENIS KELAMIN PADA KEPATUHAN PASIEN DIABETES MELITUS MENGGUNAKAN OBAT ANTIDIABETES DI PERUM KETAPANG SOKARAJA KULON
}

\author{
Ikhwan Yuda Kusuma ${ }^{1)}$, Rani Prabandani ${ }^{2)}$ \\ ${ }^{11,2)}$ Program Studi Farmasi Sekolah Tinggi Ilmu Kesehatan Harapan Bangsa Purwokerto \\ 1) $\underline{\text { ikhwanyuda@shb.ac.id, }},{ }^{2)}$ Raniprabandari@shb.ac.id
}

\begin{abstract}
ABSTRAK
Hasil survei WHO menunjukkan bahwa jumlah penderita DM di Indonesia menduduki ranking ke-4 terbesar di dunia. Penyakit DM menyebabkan kematian sebesar 5\% setiap tahunnya. Kematian akibat DM diperkirakan akan meningkat sebesar 50\% pada sepuluh tahun yang akan datang. Hasil RISKESDAS Jawa Tengah 2007 menunjukkan bahwa prevalensi penyakit DM di provinsi Jawa Tengah yaitu sebesar 0,8\% dan secara keseluruhan sebesar 1,3\%. Prevalensi tertinggi terdapat di Kabupaten Cilacap (3,9\%), urutan kedua yaitu Kabupaten Tegal Kota $(3,1 \%)$, untuk urutan ketiga yaitu Surakarta $(2,8 \%)$, urutan keempat yaitu Pemalang $(2,1 \%)$, dan urutan kelima diduduki Banyumas (1,9\%) (Depkes,2009). Penelitian ini menggunakan rancangan eksperimental dengan melakukan perlakuan terhadap kelompok kasus.Instrumen penelitian dalam penelitian ini adalah panduan wawancara tentang jumlah sisa obat antidiabetes untuk mengecek kepatuhan dan kuesioner MMAS yang sudah di validasi dan translasi versi Indonesia (Setyaningsih, 2013). Hasil analisa data dengan uji Chi-Square diperoleh $\mathrm{p}=0,220(\mathrm{p}>0,05)$ berdasarkan kuesioner MMAS, hal ini menunjukkan bahwa hal ini menunjukkan bahwa penelitian ini usia memberikan pengaruh atau memiliki hubungan yang signifikan terhadap kepatuhan penggunaan antidiabetes pada pasien DM di Perum Ketapang Sokaraja Kulon.
\end{abstract}

Kata Kunci : Usia, Diabetes Melitus, Informasi Obat,

\section{ABSTRACT}

The WHO survey results show that the number of DM patients in Indonesia is ranked the 4th largest in the world. DM causes death by 5\% every year. Deaths from DM are expected to increase by $50 \%$ in the next ten years. The results of the 2007 Central Java RISKESDAS showed that the prevalence of DM in Central Java province was $0.8 \%$ and overall was $1.3 \%$. The highest prevalence is found in Cilacap Regency (3.9\%), second place is Tegal City Regency (3.1\%), for the third place is Surakarta (2.8\%), fourth place is Pemalang (2.1\%), and fifth place is occupied by Banyumas (1.9\%) (Ministry of Health, 2009). This study used an experimental design by treating the group of cases. The research instruments in this study were interview guides about the number of remaining antidiabetic drugs to check the compliance and MMAS questionnaires that had been validated and translated into Indonesian versions (Setyaningsih, 2013). The results of data analysis using the Chi-Square test were obtained $p=0.220(p>0.05)$ based on the MMAS questionnaire, this indicates that this indicates that this study of age has a significant influence on the adherence of antidiabetic use in DM patients in Perum Ketapang Sokaraja Kulon.

Keywords: Age, Diabetes Mellitus, Drug Information 


\section{PENDAHULUAN}

Hasil survei WHO menunjukkan bahwa jumlah penderita DM di Indonesia menduduki ranking ke-4 terbesar di dunia. Penyakit DM menyebabkan kematian sebesar 5\% setiap tahunnya. Kematian akibat DM diperkirakan akan meningkat sebesar $50 \%$ pada sepuluh tahun yang akan datang. Hasil RISKESDAS Jawa Tengah 2007 menunjukkan bahwa prevalensi penyakit DM di provinsi Jawa Tengah yaitu sebesar $0,8 \%$ dan secara keseluruhan sebesar $1,3 \%$. Prevalensi tertinggi terdapat di Kabupaten Cilacap (3,9\%), urutan kedua yaitu Kabupaten Tegal Kota (3,1\%), untuk urutan ketiga yaitu Surakarta $(2,8 \%)$, urutan keempat yaitu Pemalang $(2,1 \%)$, dan urutan kelima diduduki Banyumas (1,9\%) (Depkes,2009).

Pelayanan kefarmasian merupakan bagian integral dari sistem pelayanan kesehatan yang tidak terpisahkan. Salah satu aspek pelayanan kefarmasian adalah pelayanan residensial kefarmasian yang penyelenggaraannya telah diatur dalam Pedoman Home Pharmacy Care tahun 2008. Pelaksanaan jaminan kesehatan yang diatur dalam pasal 22 Peraturan Presiden Nomor 12 Tahun 2013 mengenai jaminan kesehatan yaitu pelayanan kesehatan tingkat pertama dan pelayanan kesehatan lanjutan, dimana pelayanan kesehatan tingkat pertama memberikan pelayanan yang bersifat preventif dan promotif kepada peserta serta dalam pelayanannya terdapat kerja kerjasama antara dokter, perawat dan farmasis. Hasil penelitian menunjukkan bahwa pelayanan residensial kefarmasian mampu meningkatkan kepatuhan penggunaan obat pasien dan diet pada pasien, sehingga dapat menunjang keberhasilan terapi pasien (Ichwari et al., 2013).

Komplikasi DM dapat dicegah dengan meningkatkan kepatuhan penggunaan obat dan diet pasien sehingga dapat memaksimalkan outcome terapi (Depkes, 2005). Kepatuhan terhadap pengobatan adalah faktor utama dari outcome terapi (Morello et al., 2011). Penelitian Cramer (2004) menunjukkan bahwa beberapa pasien DM tipe 2 tidak mengkonsumsi sepenuhnya obat diabetes oral yang diresepkan oleh dokter dan tingkat kepatuhan secara keseluruhan menurun setiap waktu. Faktor-faktor yang dapat mempengaruhi kepatuhan meliputi pemahaman pasien dari regimen dan manfaatnya, efek samping yang potensial, biaya dan kompleksitas dari terapi 
(Osterberg and Blaschke, 2005). lebih melihat ke depan (Perwitasari, 2010). Kompleksitas regimen obat dipengaruhi Tujuan penelitian ini adalah untuk oleh jumlah obat, frekuensi pemberian, mengetahui pengaruh suatu variabel bentuk sediaan dan juga instruksi independen (pemberian informasi obat) pemberian khusus (Pollack et al., 2010). terhadap variabel dependen (kepatuhan

Berdasarkan adanya penerapan program jaminan kesehatan dan hasil survei yang menunjukkan bahwa Surakarta menjadi peringkat ketiga dalam jumlah penderita diabetes serta tingkat kepatuhan pasien DM yang masih rendah, maka peneliti bermaksud untuk melakukan konseling dengan menggunakan alat bantu (lembar informasi penggunaan obat dan telepon) serta melihat hubungannya terhadap tingkat kepatuhan, outcome klinik dan tingkat kepuasan pasien DM tipe2 . Penelitian ini diharapkan bahwa dengan adanya peningkatan kepatuhan maka outcome klinik akan tercapai dan tingkat kepuasan pasien juga menjadi semakin meningkat.

\section{METODE PENELITIAN}

Penelitian ini menggunakan
rancangan eksperimental dengan
melakukan perlakuan terhadap kelompok
kasus. Subjek dialokasikan secara random
atau penelitian acak terkontrol dengan cara
pengambilan data secara prospektif atau
data diambil setelah penelitian dimulai dan
pasien). Penelitian dilakukan dengan mengamati pasien DM yang diberi informasi obat (kelompok kasus) dan tanpa informasi obat (kelompok kontrol) saat pengambilan obat, kemudian mengamati tingkat kepatuhan pasien dalam minum obat antidiabetes.

Instrumen penelitian dalam penelitian ini adalah panduan wawancara tentang jumlah sisa obat antidiabetes untuk mengecek kepatuhan dan kuesioner MMAS yang sudah di validasi dan translasi versi Indonesia (Setyaningsih, 2013). Data rekam medik untuk mengetahui data pasien dan hasil diagnosa pasien DM oleh dokter.

Sampel yang digunakan dalam penelitian ini yaitu menggunakan pasien yang terdiagnosa DM dengan melihat kartu kendali atau kartu kontrol kesehatan pasien yang sudah tertulis atau terdata oleh petugas kesehatan dan mendapatkan antidiabetes oleh dokter di Perum Ketapang Sokaraja Kulon pada tanggal 30 April-30 Mei 2018 jam 08.00-12.00 WIB. Jumlah sampel pada penelitian ini diperoleh 
sebanyak 44 responden.

Peneliti dalam mengumpulkan data pasien DM pada Bulan Mei 2018. Data yang diambil meliputi nama obat, umur, dan alamat pasien. Data mengenai kepatuhan pasien DM menggunakan data primer, yaitu melalui wawancara secara langsung kepada pasien, yaitu data dari jumlah sisa obat yang diminum oleh pasien pada hari ke 3 serta pengisian kuesioner MMAS.

Data dianalisis statistik ChiSquare bertujuan untuk mengetahui adanya hubungan atau pengaruh dua variable nominal (Uji independen antara dua variable).

\section{HASIL DAN PEMBAHASAN}

Pengaruh usia dan jenis kelamin terhadap tingkat kepatuhan

Pada penelitian ini peneliti ingin mengetahui pengaruh usia dan jenis kelamin terhadap tingkat kepatuhan. Hasil wawancara berdasarkan kuisioner MMAS diperoleh data dari hasil uji statistik seperti pada Tabel II.
Berdasarkan uji statistik dengan uji Chi-Square diperoleh data hasil pengaruh usia terhadap tingkat kepatuhan dengan nilai $\mathrm{p}=0,071 \quad(\mathrm{p}>0,05)$. Pada usia tidak terdapat hubungan yang signifikan terhadap tingkat kepatuhan pasien DM pada penggunaan antidiabetes, sedangkan pengaruh jenis kelamin terhadap tingkat kepatuhan dengan nilai $\mathrm{p}=0,950(\mathrm{p}>0,05)$, tidak terdapat hubungan yang signifikan terhadap tingkat kepatuhan pasien DM pada penggunaan antidiabetes. Hal ini menunjukkan pada kelompok usia baik usia 20-59 tahun dan 60-79 tahun sama-sama peduli terhadap kesehatan sehingga memiliki kesadaran untuk sembuh sehingga tingkat kepatuhan pasien tidak ada pengaruh terhadap usia dalam penggunaan antidiabetes pada pasien DM. Sedangkan pada jenis kelamin perempuan dan laki-laki kemungkinan sama-sama teliti dan telaten dalam mengkonsumsi obat antidiabetes sehingga tingkat kepatuhan pasien tidak ada pengaruh terhadap jenis kelamin dalam penggunaan antidiabetes pada pasien DM. 
Tabel II. pengaruh usia dan jenis kelamin terhadap tingkat kepatuhan pasien DM

\begin{tabular}{ccccccc}
\hline $\begin{array}{c}\text { Karakteristik } \\
\text { Responden }\end{array}$ & \multicolumn{2}{l}{ Tingkat Kepatuhan } & Total & p & OR & $\mathrm{Cl}$ \\
\cline { 2 - 4 } Usia (n: 44) & Rendah & Tinggi & & & & \\
\hline $20-59$ & 10 & 21 & 31 & 0,071 & 0,298 & $\begin{array}{c}0,077- \\
1,145\end{array}$ \\
\hline $60-79$ & 8 & 5 & 13 & & & \\
\hline Total & 18 & 26 & 44 & & & \\
\hline $\begin{array}{c}\text { Jenis kelamin } \\
\text { (n:44) }\end{array}$ & & & & & & \\
\hline Perempuan & 13 & 19 & 32 & 0,950 & 0,958 & $0,249-$ \\
\hline Laki-laki & 5 & 7 & 12 & & & 3,684 \\
\hline Total & 18 & 26 & 44 & & & \\
\hline
\end{tabular}

Hasil kepatuhan pasien berdasarkan usia dan jenis kelamin

Setelah didapatkan tingkat kepatuhan pasien berdasarkan kuesioner MMAS peneliti membuktikan kebenaran kepatuhan pasien DM dalam penggunaan antidiabetes berdasarkan jumlah sisa obat yang dilihat saat peneliti berkunjung kerumah pasien pada hari ke-3.

Pada penelitian ini peneliti ingin mengetahui pengaruh usia dan jenis kelamin terhadap kepatuhan. Berdasarkan hasil wawancara tentang jumlah sisa obat diperoleh data dari hasil uji statistik seperti pada Tabel V.

Berdasarkan hasil uji statistik dengan uji Chi-Square diperoleh data hasil pengaruh usia dan jenis kelamin terhadap kepatuhan. Diperoleh hasil data dengan nilai $p$ sebesar $0,000 \quad(\mathrm{p}<0,05)$ pada kelompok usia dan nilai $\mathrm{p}$ sebesar 0,530 $(\mathrm{P}>0,05)$ pada kelompok jenis kelamin. Maka pada penelitian ini usia memberikan pengaruh atau memiliki hubungan yang signifikan terhadap kepatuhan penggunaan antidiabetes pada pasien DM. 
Tabel V. Pengaruh usia dan jenis kelamin terhadap tingkat kepatuhan

\begin{tabular}{|c|c|c|c|c|c|c|}
\hline \multirow{2}{*}{$\begin{array}{l}\text { Karakteristik } \\
\text { Responden }\end{array}$} & \multicolumn{2}{|c|}{ Tingkat Kepatuhan } & \multirow[t]{2}{*}{ Total } & \multirow[t]{2}{*}{$\mathrm{p}$} & \multirow[t]{2}{*}{ OR } & \multirow[t]{2}{*}{$\mathrm{Cl}$} \\
\hline & Rendah & Tinggi & & & & \\
\hline \multicolumn{7}{|l|}{ Usia (n: 44) } \\
\hline $20-59$ & 31 & 0 & 31 & \multirow{2}{*}{0,000} & \multirow{2}{*}{1,857} & $1,123-$ \\
\hline $60-79$ & 7 & 6 & 13 & & & 3,072 \\
\hline \multirow[t]{2}{*}{ Total } & 38 & 6 & \multirow[t]{2}{*}{44} & & & \\
\hline & $86,36 \%$ & $13,64 \%$ & & & & \\
\hline \multicolumn{7}{|l|}{$\begin{array}{l}\text { Jenis kelamin } \\
(\mathrm{n}: 44)\end{array}$} \\
\hline Perempuan & 27 & 5 & 32 & \multirow{2}{*}{0,530} & \multirow{2}{*}{0,491} & $0,051-$ \\
\hline Laki-laki & 11 & 1 & 12 & & & 4,698 \\
\hline \multirow[t]{2}{*}{ Total } & 38 & 6 & 44 & & & \\
\hline & $86,36 \%$ & $13,64 \%$ & & & & \\
\hline
\end{tabular}

\section{KESIMPULAN}

Berdasarkan hasil penelitian dapat disimpulkan bahwa Hasil analisa data dengan uji Chi-Square diperoleh $\mathrm{p}=0,220$ ( $p>0,05)$ berdasarkan kuesioner MMAS, hal ini menunjukkan bahwa penelitian ini usia memberikan pengaruh atau memiliki hubungan yang signifikan terhadap kepatuhan penggunaan antidiabetes pada pasien DM di Perum Ketapang Sokaraja Kulon.

\section{DAFTAR PUSTAKA}

Ahmad, N.S., Ramli, A., Islahudin, F., Paraidathathu, T., 2013. Medication Adherence in Patients with Tipe 2 Diabetes Mellitus
Treated at Primary Health Clinics in Malaysia. Patient Prefer Adherence. Dove Medical Press 7 , 525-530. doi:10.2147/PPA.S44698

American Diabetes Association, 2012. Standards of Medical Care in Diabetes-- 2012. Diabetes Care, 35, S11-S63. doi:10.2337/dc12S011

American Diabetes Association, 2014. Standards of Medical Care in Diabetes-- 2014. Diabetes Care, 37, S14-S80. doi: 10.2337/dc14S014

American Diabetes Association., 2015. American Diabetes Association Standards of Medical Care in Diabetes-2015. Diabetes Care, 38, S1-S94.

Anderson, R.T., Girman, C.J., Pawaskar, 
M.D., Camacho, F.T., Calles, J., Kelly, W.S., DeMuro, C., Balkrishnan, R., 2009. Diabetes Medication Satisfaction Tool A focus on treatment regimens. Diabetes Care 32, 51- 53. doi: $10.2337 / \mathrm{dc} 08-0856$

Anonim. 2013. Peraturan Presiden Republik Indonesia Nomor 12 tahun 2013 tentang Jaminan Kesehatan.

Avramopoulos, I., Moulis, A., Nikas, N., 2015. Glycaemic control, treatment satisfaction and quality of life in type 2 diabetes patients in Greece: The PANORAMA study Greek results. World J. Diabetes 6, 208-216. doi:10.4239/wjd.v6.i1.208

Barbosa, CD., Balp MM, Kulich, K., Germain N., Rofail D., 2012., A Literature Review to Explore The Link Between treatment Satisfaction and Adherence,
Compliance, and Persistence. Patient Prefer Adherence; 6: 3949.

BPJS Kesehatan, 2013. Panduan Praktis PROLANIS (Program Pengelolaan Penyakit kronis). BPJS Kesehatan. Jakarta.

Avramopoulos, I., Moulis, A., Nikas, N., 2015. Glycaemic control, treatment satisfaction and quality of life in type 2 diabetes patients in Greece: The PANORAMA study Greek results. World J. Diabetes 6, 208-216. doi:10.4239/wjd.v6.i1.208

Bradley, C., Lewis, K.S., 1990. Measures of psychological well-being and treatment satisfaction developed from the responses of people with tablet- treated diabetes. Diabet. Med. J. Br. Diabet. Assoc. 7, 445-451. 